\title{
Why there's no point telling me to lose weight
}

\section{Emma Lewis}

This is one of a new monthly series in which patients and carers set the learning outcomes for readers. For more information contact Rosamund Snow, patient editor, rsnow@bmj.com

I am one of over $97 \%$ of people for whom dieting does not lead to sustained weight loss. ${ }^{1-3}$

I've experienced health benefits from increased exercise, and from switching to a wholemeal vegetarian diet. My blood pressure's normal, as are my fasting glucose and my lung function - as far as I can tell, my health is great. But my body mass index (BMI) has been above 30 my entire adult life.

When I worry that I might be unwell, I often try to avoid visiting a general practitioner. Almost every consultation I've ever had-about glandular fever, contraception, a sprained ankle-has included a conversation about my weight; and that's inevitably the conversation that destroys any rapport or trust that might have existed between me and my doctor.

Fighting "the obesity epidemic" is supposed to be about making me-as a "severely obese" person-more healthy; but the impact of obesity rhetoric on my life has been quite the opposite.

I've been out dancing in some slightly inadvisable shoes. On the walk home, I step awkwardly in a gutter and hurt my ankle. The next morning, the swelling is pretty severe, so I decide I ought to get it checked out.

The doctor tells me that I should be exercising more. I say: I know that increased circulation boosts healing, but as it currently hurts to stand I'm not sure what it's best to do for exercise. He says: he's not talking about healing up the ankle, he means, in general.

He hasn't asked me how much exercise I already do. He doesn't know that just last night I danced energetically for four hours then walked several miles home. I assume that he tells all his fat patients the same thing, without bothering to find out about their individual situations. This doesn't exactly fill me with trust that I'm receiving responsible medical advice. I don't visit this practice again.

I have been fat my whole life. So when healthcare professionals ask me-in the middle of a consultation about something completely unrelated — whether I know that my BMI is too high and whether I'm engaged in any weight management, I'm always a little surprised when they act like they might be the first to have ever brought it up. As if I might have made it through my 30 years without ever once noticing that I was fat and that some people think that fat is bad.

It's just a little reminder that my GP-like many other people in the world—sees me as a fat person first, and an individual second. It makes me feel like a problem to be solved-something unpleasant that needs to be eliminated.

I recently took up weightlifting. I'm happier in myself now-my stamina has increased, as has my strength; I can cycle up hills that used to defeat me.

Unfortunately, building up enough muscle mass to squat a 100 kg barbell has tipped my BMI over from "obese" to "severely obese." I haven't been back to a GP since, but I'm dreading it more than ever.

When health professionals bring up my weight in a consultation, I don't feel like they're looking out for my health. All my health markers are fine, I'm active and happy, and I've spent years fighting against the low self esteem that came from an adolescence spent believing that I'd never be attractive to anyone, yet they still think that it's important to tell me to do something that I know to be impossible. They give me the impression that my weight is the most important thing about me-more important than, say, my penchant for body piercing and platform shoes, both of which have caused me more infection and injury than my adipose tissue has. They put me right back to where I was when I was a binging-fasting teenager: full of shame.

They tell me that my body type is a "risk factor" for all kinds of diseases, and that statistically I'm more likely to be healthy if I lose weight. I might query the science behind that supposition—citing the "obesity paradox," which indicates that fat people have better survival rates than thin people for all sorts of diseases, ${ }^{4-6}$ but I do accept that it's orthodox medical opinion.

Even if I did want to change my body type to be less of a "risk factor"-it's not that easy. I'm already physically active well beyond the recommendations of the chief medical officer, ${ }^{7}$ and I don't rate my chances of being one of those seemingly mythical people who manage to maintain weight loss through dietary intervention. ${ }^{1-3}$

My childhood contained so many diets, so many humiliations in school PE (physical education). No attempts to make me lose weight have ever had any long term effects. All they did was give me a constant sense of shame and of not being good enough. This led to unhealthy eating habits that would have been labelled "disordered" in someone with a lower BMI. It has taken me years to unlearn those habits. And it's only recently that I've really discovered the joys of physical exertion, having spent most of my life thinking of exercise as "that punishment I get given for being fat"-impact based activities like running are physically painful for someone with my body type. 
I've opted out of the weight loss game. If that makes me a non-compliant patient, then so be it. I'm healthier and happier than I was when I hated myself. I just wish that my healthcare providers would work with me on that.

I have read and understood the BMJ Group policy on declaration of interests and declare the following interests: None.

Provenance and peer review: Commissioned; not externally peer reviewed.

Mann T, Tomiyama AJ, Westling E, Lew AM, Samuels B, Chatman J. Medicare's search for effective obesity treatments: diets are not the answer. Am Psychologist 2007;3:220-33. 2 Jeffery RW, Epstein LH, Wilson GT, Drewnowski A, Stunkard, AJ, Wing RR. Long-term maintenance of weight loss: current status. Health Psychol 2000;19:5-16.
3 Kramer FM, Jeffery RW, Forster JL, Snell MK. Long-term follow-up of behavioral treatment for obesity: patterns of weight regain among men and women. Int J Obesity 1989:13:123-36.

4 Kamyar KZ, Vaidyanathapuram SB. The kidney disease wasting: Inflammation, oxidative stress, and diet-gene interaction. Hemodialysis Int 2006;10:315-25.

5 Kang X, Shaw LJ, Hayes SW, Hachamovitch R, Abidov A, Cohen I, et al. Impact of body mass index on cardiac mortality in patients with known or suspected coronary artery disease undergoing myocardial perfusion single-photon emission computed tomography. J Am Coll Cardiol 2006;47:1418-26.

6 Hainer V, Aldhoon-Hainerova I. Obesity paradox does exist. Diabetes Care 2013;36:276-81.

7 Chief Medical Office. Factsheet 4: physical activity guidelines for adults (19-64 years) 2011.

8 Bacon L, Aphramor L. Weight science: evaluating the evidence for a paradigm shift. Nutrition J 2011:10:9.

Cite this as: BMJ 2015;350:g6845

(c) BMJ Publishing Group Ltd 2015 


\section{Key messages}

1. Focus on what the patient has come to see you about today. If you only do that, you've done a good job. Think twice before offering unsolicited advice in the guise of "education," particularly when your patient is consulting you about something unrelated. If your patients hear the same potted advice during every appointment, it'll soon lose its impact; and if you insist on bringing up a subject that they find traumatic you could put them off seeking your advice in future.

2. It is appropriate to give diet or exercise advice when somebody asks you directly, but try to focus on the other benefits of eating well and getting regular exercise, rather than treating weight loss as an end in itself. ${ }^{8}$ That way your patients won't get discouraged from healthy behaviours even when they do not result in permanent weight loss.

3. Fat people know that they are fat. You don't need to tell us; society's been doing that our whole lives. Many of us have been traumatised by constant reminders about weight loss culture-about how shameful you seem to find our bodies.

\section{CPD/CME questions}

- This author directly questions the role of the healthcare professional with respect to conventional health promotion. What is your reaction to that?

- How would you work with Emma if she walked into your surgery or clinic tomorrow? 